\title{
Allelopathic activity of Azadirachta indica A.Juss. on Handroanthus serratifolius (Vahl) S.Grose
}

\author{
Atividade alelopatica de Azadirachta indica A.Juss. sobre Handroanthus serratifolius (Vahl) S.Grose \\ Actividad alelopática de Azadirachta indica A.Juss. sobre Handroanthus serratifolius (Vahl) S.Grose
}

\begin{abstract}
Allelopathy involves the direct or indirect, stimulating or inhibiting action, promoted by substances called allelochemicals which, when released into the environment, can interfere positively or negatively in the development and germination of surrounding species. The objective of this work was to evaluate the allelopathic potential of Azadirachta indica A.Juss (Meliaceae) leaves on seed germination and seedling development of Handroanthus serratifolius (Vahl) S.Grose (Bignoniaceae). The experimental design used was completely randomized with four treatments and a control group (distilled water). Each treatment consisted of four replicates of 15 seeds each. The aqueous extract was prepared by grinding $250 \mathrm{~g}$ of fresh leaves in $1 \mathrm{~L}$ of distilled water, where further dilutions were made at concentrations of $25 \%, 50 \%, 75 \%$ and $100 \%$. Germination rate, germination speed index (IVG), radicle length and stem length were analyzed. In addition to the $\mathrm{pH}$ and osmolarity of the extracts. And the phytochemical prospection to determine the main classes of secondary metabolites. Seed germinability was only affected by the extract at $100 \%$ concentration. It was also observed a reduction in the length of the stems and radicles of seedlings subjected to extracts at the highest concentrations. The observed effect may be due to the presence of alkaloids, flavonoids and phenolic compounds, since these compounds have proven action on the development of seedlings.
\end{abstract}

Keywords: Allelochemicals; Invasive species; Phytochemistry.

\section{Resumo}

A alelopatia implica na ação direta ou indireta, estimuladora ou inibidora, promovida por substâncias químicas denominadas de aleloquímicos que quando liberados no ambiente podem interferir de maneira positiva ou negativa no desenvolvimento e germinação de espécies circunvizinhas. O objetivo com este trabalho foi avaliar o potencial 
alelopático de folhas de Azadirachta indica A.Juss (Meliaceae), sobre a germinação de sementes e desenvolvimento de plântulas de Handroanthus serratifolius (Vahl) S.Grose (Bignoniaceae). O delineamento experimental utilizado foi o inteiramente casualizado com quatro tratamentos e um grupo controle (água destilada). Cada tratamento constou de quatro repetições de 15 sementes cada. $\mathrm{O}$ extrato aquoso foi preparado através da trituração de $250 \mathrm{~g}$ de folhas frescas em $1 \mathrm{~L}$ de água destilada, onde posteriormente foram feitas as diluições nas concentrações de $25 \%, 50 \%, 75 \%$ e $100 \%$. Foram analisadas a germinabilidade, Índice de Velocidade de Germinação (IVG), comprimento da radícula e comprimento do caulículo. Além do $\mathrm{pH}$ e osmolaridade dos extratos. E da prospecção fitoquímica para determinação das principais classes de metabólitos secundários. A germinabilidade das sementes, foi afetada somente pelo extrato a $100 \%$ de concentração. Foi observado também uma redução no comprimento dos caulículos e radículas das plântulas submetidas aos extratos nas maiores concentrações. $O$ efeito observado pode se dever a presença de alcaloides, flavonoides e compostos fenólicos, uma vez que tais compostos tem ação comprovada sobre o desenvolvimento de plântulas.

Palavras-chave: Aleloquímicos; Espécie invasora; Fitoquímica.

\section{Resumen}

La alelopatía implica la acción directa o indirecta, estimulante o inhibidora, promovida por sustancias químicas llamadas aleloquímicos que, cuando se liberan al medio ambiente, pueden interferir positiva o negativamente en el desarrollo y germinación de las especies circundantes. El objetivo de este trabajo fue evaluar el potencial alelopático de las hojas de Azadirachta indica A. Juss (Meliaceae) sobre la germinación de semillas y el desarrollo de plántulas de Handroanthus serratifolius (Vahl) S.Grose (Bignoniaceae). El diseño experimental utilizado fue completamente al azar con cuatro tratamientos y un grupo control (agua destilada). Cada tratamiento consistió en cuatro repeticiones de 15 semillas cada una. El extracto acuoso se preparó triturando $250 \mathrm{~g}$ de hojas frescas en $1 \mathrm{~L}$ de agua destilada, donde se hicieron más diluciones a concentraciones de $25 \%, 50 \%, 75 \%$ y $100 \%$. Se analizaron la tasa de germinación, el índice de velocidad de germinación (IVG), la longitud de la radícula y la longitud del tallo. Además del pH y osmolaridad de los extractos. Y la prospección fitoquímica para determinar las principales clases de metabolitos secundarios. La germinabilidad de la semilla solo se vio afectada por el extracto al 100\% de concentración. También se observó una reducción en la longitud de los tallos y radículas de las plántulas sometidas a extractos en las concentraciones más altas. El efecto observado puede deberse a la presencia de alcaloides, flavonoides y compuestos fenólicos, ya que estos compuestos han demostrado su acción sobre el desarrollo de las plántulas.

Palabras clave: Aleloquímicos; Especies invasivas; Fitoquímica.

\section{Introduction}

Allelopathy is a phenomenon responsible for a direct or indirect, stimulating or inhibiting action, triggered by chemical substances produced by plant metabolism, which, when released into the environment, can influence the development of other organisms in the community (Rice, 2012). Such substances, called allelochemicals, when released in sufficient quantities into the environment, can positively or negatively interfere in the germination and development process of other species found around them (Almeida et al., 2008; Taiz et al., 2017).

It is an important ecological mechanism, influencing the composition of native vegetation in different ecosystems, the succession of species, and the management and production of agricultural crops (Oliveira et al., 2011). Several invasive species have allelopathic potential and can act to control others through the allelochemicals produced by secondary metabolism. Such compounds, once isolated, can be used as natural herbicides, which is a safe and effective procedure, since such products are formulated from natural biodegradable compounds and do not remain in the environment as a pollutant (Oliveira Junior et a., 2001).

Invasive species can affect the structure of communities through changes in the diversity or abundance of native plants. Seedlings may encounter some ecological restrictions during germination and establishment. These factors can be abiotic, such as temperature, water, soil, among others, or biotic such as cattle grazing, competition, herbivory and allelopathy (Alves et al., 2006).

The success of invasive species is due to their ability to adapt to environmental factors. Such species can interfere in several cultures, causing a decrease in production, as they compete for resources present in the soil, such as nutrients, water, light and through the release of allelopathic substances which contaminate the soil in the environments where they are present (Inoue et al., 2010). 
Meliaceae species are promising for having biologically active compounds that influence the development of other organisms (Rickli et al., 2011). Among which Azadirachta indica A.Juss., commonly called Indian neem, due to the insecticidal activity attributed to it (Schmutterer, 1990; Koul et al., 1990) for being efficient in low concentrations, presenting low toxicity to mammals and for its activity proven on approximately 400 species of insects (Gallo et al., 2002; Bogorni et al., 2005).

The Indian neem is a peculiar plant, as it does not run the risk of extinction caused by over-harvesting, since the active substances are found in the seeds and leaves; by the difficulty of insects to become resistant, as it has a great diversity of insecticidal substances; by the high concentration of water-soluble active substances, easy to extract and low cost; by the high toxicity of the substances in relation to pests and by the innocuousness to man and the environment, as its active principles are biodegradable and of low permanence (Barrek, Paisse, Grenier-Loustalot 2004).

According to Moro et al., (2011), since 2006, the cultivation of A. indica has been intensified in Northeastern Brazil, both in commercial plantations and as an ornamental or shade species. Currently, it is one of the most used ornamental trees in countless cities in Northeastern Brazil, and it may become an invasive species in preserved and anthropized natural environments, requiring greater knowledge about its activity in relation to native species in such environments.

Considering these aspects, this research sought to determine the allelopathic effect of $A$. indica on seed germination and the initial development of seedlings of Handroanthus serratifolius (Ipê-amarelo), a native species in caatinga areas, as well as to identify and characterize the seedlings. chemical compounds responsible for the allelopathic action observed.

\section{Methodology}

\subsection{Collection and identification of botanical material}

Vegetative material (leaves) and reproductive material (flowering branches) of Azadirachta indica (donor species) were collected in September 2018 in the municipality of Crato $\left(07^{\circ} 14^{\prime 2} 278^{\prime \prime}\right.$ S and $\left.039^{\circ} 24^{\prime} 974^{\prime \prime} \mathrm{W}\right)$ at $441 \mathrm{~m}$ of altitude (Figure 1). Concomitantly, seeds of Handroanthus serratifolius (recipient species) were collected in the municipality of Juazeiro do Norte, $\left(07^{\circ} 13^{\prime} 364^{\prime \prime} \mathrm{S}\right.$ and 39 $20^{\prime} 242^{\prime}$ W) at $438 \mathrm{~m}$ altitude, both in the state of Ceará. The collected species were treated according to the usual herborization techniques and incorporated into the collection of the Herbarium Caririense Dárdano de Andrade-Lima (HCDAL) of the Regional University of Cariri (URCA), under registration number 13,920 (A. indica), 14,216 (H. serratifolius).

\subsection{Preparation of plant extracts and bioassays}

The experiments were carried out at the Laboratory of Applied Botany (LBA) of the Regional University of Cariri (URCA). To prepare the extract, $250 \mathrm{~g}$ of fresh leaves of $A$. indica were ground in $1 \mathrm{~L}$ of distilled water, in an industrial blender, for one minute. After milling, the extract was filtered and centrifuged for 5 minutes at 3000 rpm. With the supernatant removed from the remaining extract (100\% extract), dilutions were made with distilled water to 75, 50 and $25 \%$ (Treatments). The control group consisted of only 0\% distilled water, according to the modified methodology of Gliessman \& Müller (1978).

The germination bioassays consisted of four replications of 15 seeds each of $H$. serratifolius, equidistantly distributed in gerbox boxes with two sheets of Germitest ${ }^{\circledR}$ paper moistened with $10 \mathrm{ml}$ of extract at different concentrations as substrate. To avoid evaporation of extracts, after seed distribution, the boxes were sealed with PVC film. The experiments were kept in a germination chamber for biological oxygen demand (BOD) at a temperature $\pm 27^{\circ} \mathrm{C}$ and photoperiod \pm 12 hours. 
Figure 1: Map with the locations of the collections of Azadirachta indica and Handroanthus serratifolius.

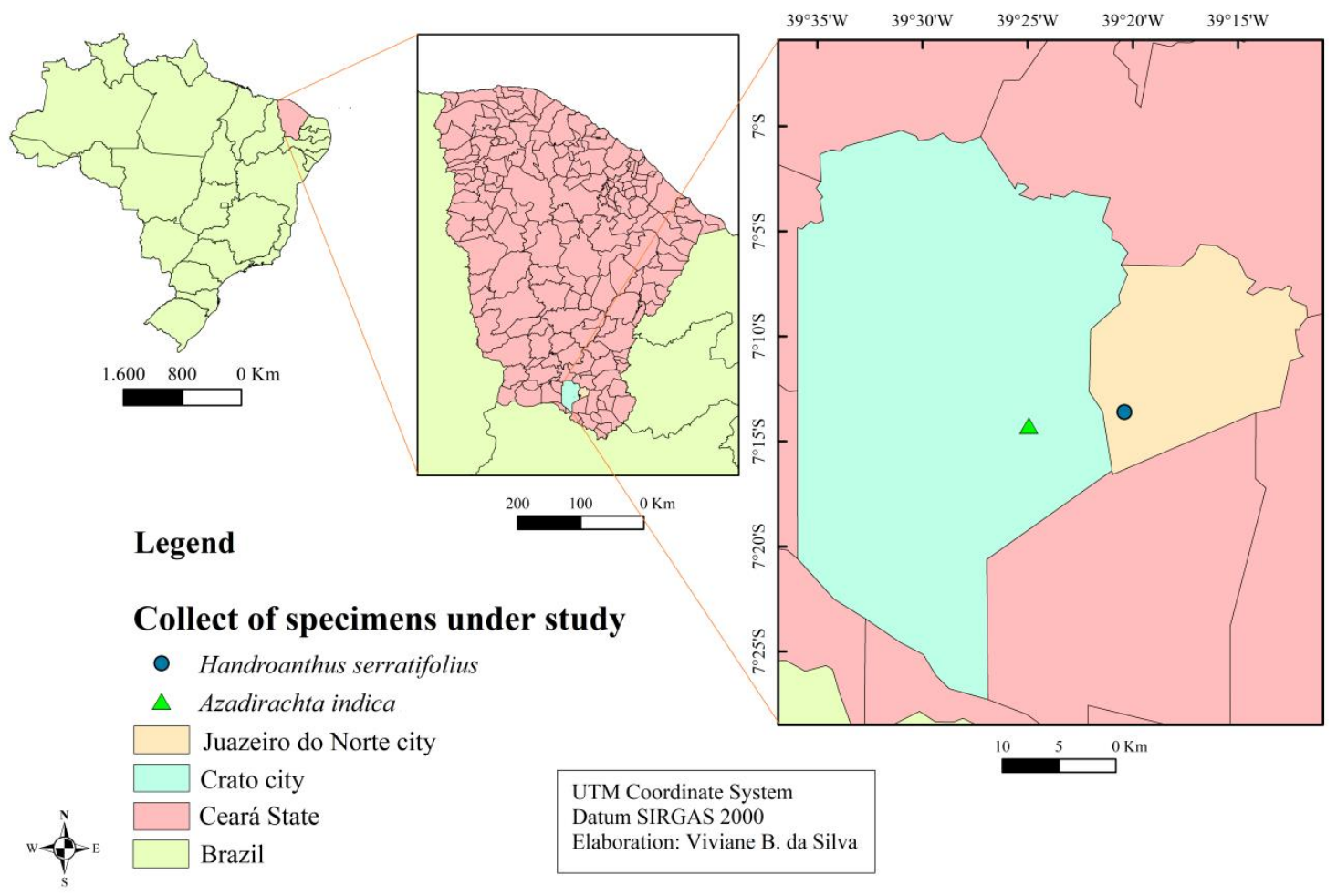

Source: Authors (2021).

\subsection{Variables analyzed}

\subsubsection{Germinability}

Germination was evaluated every 24 hours, for seven days, considering germinated seeds that presented root protrusion of approximately $5 \mathrm{~mm}$ in length.

The percentage values of germinability were obtained using the formula proposed by Azevedo Neto (2010): G=(N/A) $\times 100$, where: $\mathrm{G}=$ germinability; $\mathrm{N}=$ number of germinated seeds; $\mathrm{A}=$ total number of seeds placed to germinate.

\subsubsection{Germination Speed Index (IVG)}

The Germination Speed Index was calculated according to Maguire (1962), using the formula IVG $=(\mathrm{G} 1 / \mathrm{N} 1)+$ $(\mathrm{G} 2 / \mathrm{N} 2)+(\mathrm{Gn} / \mathrm{Nn})$, where: G1, G2, Gn = number of seeds germinated computed in the first, second and last count. N1, N2, $\mathrm{Nn}=$ number of days from sowing to the first, second and last count. The record of the amount of germinated seeds was daily.

\subsubsection{Length of the stem and radicle}

After seven days of germination, five seedlings from each gerbox box were randomly chosen for the biometry of the stem and radicle. The measurement of these structures was performed with the aid of a millimeter ruler.

\subsection{Statistical analysis}

For the statistical analysis of the data, the GraphPad Prism 6 program was used, using analysis of variance (ANOVA) and comparison of means through Regression Analysis or Tukey's Test and 5\% probability. 


\subsection{Physicochemical characteristics of extracts}

The hydrogenic potential and osmolarity of the extracts were analyzed with the aid of a pHmeter and an Osmometer, respectively. Data referring to osmolarity were obtained in $\mathrm{mOsm} / \mathrm{kg}$ and converted to osmotic pressure (MPa) using the formula proposed by Larcher (2004): $\pi=-\mathrm{W} \times 0.00832 \times$ Tabs, where: $\pi=$ Osmotic Pressure in MPa; W $=$ Osmotic Potential in Osm/kg and Tabs = Absolute temperature, expressed in degrees Kelvin.

\subsection{Phytochemical characterization}

The tests for the phytochemical characterization were carried out at the Laboratory for Research in Natural Products (LPPN) of the Regional University of Cariri (URCA). To determine the classes of secondary metabolites, freeze-dried aqueous extracts were used. The tests were carried out according to the method proposed by Matos (2006) aiming to identify the classes of secondary metabolites present in the extracts, through color change and/or formation of precipitate through cascades of chemical reactions after the addition of specific reagents.

\section{Results and Discussion}

The germination percentage of Handroanthus serratifolius was not affected by the aqueous extract of Azadirachta indica in most concentrations tested, except for the concentration of $100 \%$ where a significant difference was recorded when compared to the control (Figure 2). This result may be due to the higher concentration of allelochemicals present in that extract. Ferreira et al., (2000) consider that seed germination is less sensitive to allelochemicals than seedling growth. However, in relation to experimental quantification, it is much simpler, because for each seed the phenomenon is discrete, since either the seed germinates or it does not germinate.

The effects of allelochemicals on plant germination and development are secondary manifestations due to effects initially occurring at the cellular and molecular level. The same authors also point out that alterations in the germination pattern can result in effects on membrane permeability, on DNA transcription and translation, on the functioning of secondary messengers, alteration of respiration, conformation of enzymes and receptors, or even by the combination of such factors.

Often, allelopathic action has a more effective effect on seed germination speed than on germinability (Ferreira \& Borghetti, 2004, Formagio et al., 2010). Richardson \& Williamson (1988) attribute this fact to the nonspecificity of allelochemicals, since the same substance can perform different functions, considering its concentration and chemical composition.

Figure 2: Percentage of germination of Handroanthus serratifolius seeds subjected to Azadirachta indica extract at different concentrations.

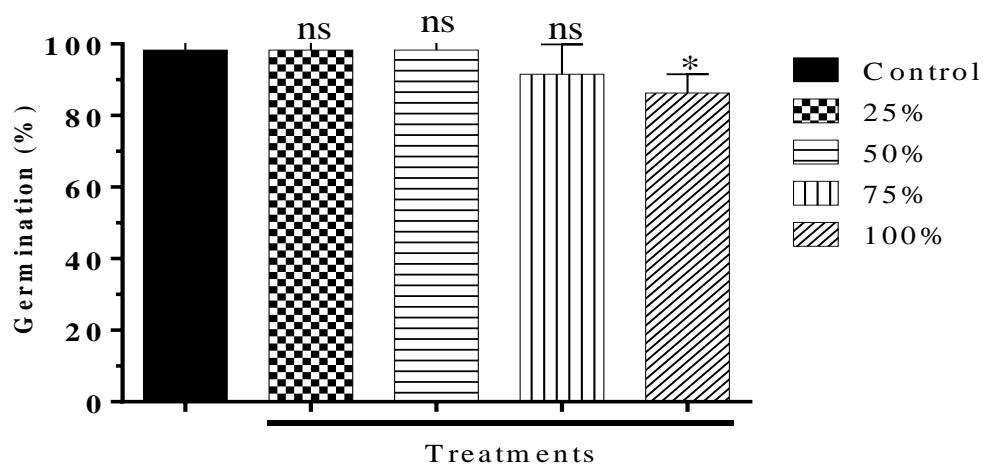

One-way analysis of variance (ANOVA). Mean ( \pm standard deviation). ns: no statistical significance. *p<0.05 compared to the control. Source: Authors (2021). 
The extract of Azadirachta indica had a negative effect on the germination speed index of Handroanthus serratifolius, delaying the germination speed from a concentration of $25 \%$, being more significant at concentrations of $75 \%$ and $100 \%$, where a lower speed was observed. of germination and greater significant differences (Figure 3). As analyzed by some authors, changes in the speed of germination can have several ecological consequences, since seeds that germinate more slowly can give rise to seedlings of reduced size, thus increasing the probability of being attacked by microorganisms present in the soil (Jefferson et al., 2003; Dadkhah et al., 2010; Oliveira et al., 2012).

Figure 3: Germination Speed ndex (GVI) of Handroanthus serratifolius seeds subjected to Azadirachta indica extract at different concentrations.

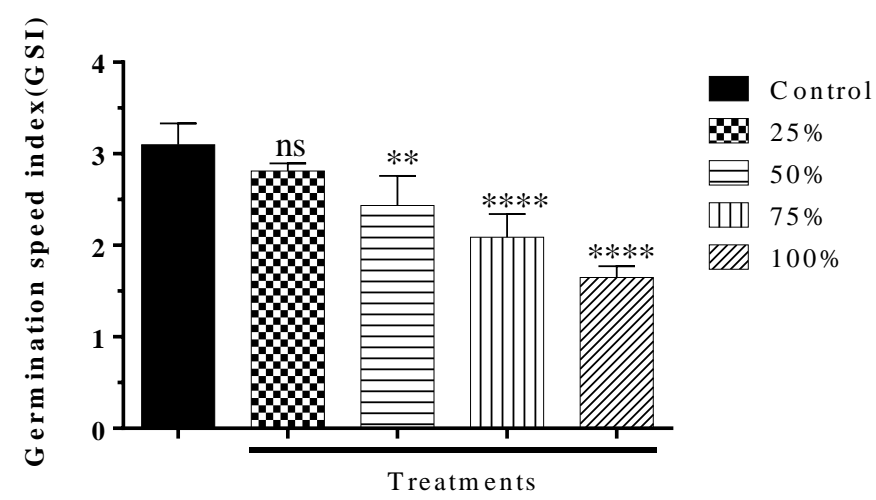

One-way analysis of variance (ANOVA). Mean ( \pm standard deviation). ns: no statistical significance. *p<0.05 compared to the control. Source: Authors (2021).

The aqueous extract of Azadirachta indica interfered negatively in the development of stems and radicles of seedlings of Handroanthus serratifolius, being significant at all concentrations tested (Figures 4 and 5). For Chung, et al., (2001), the rootlets are more affected by allelopathy because they are in direct contact with the substrate. Some authors suggest that the inhibitory effect occurs because the rootlets absorb the bioactive components present in the environment (Ferreira et al., 2000; Turk et al., 2002).

According to Souza Filho et al., (2009), the biological activity of a given allelochemical depends both on the concentration and on the response threshold of the affected species. The inhibition threshold for a given substance is not constant, but is closely related to the sensitivity of the receptor species, plant processes and environmental conditions.

Figure 4: Stem development of Handroanthus serratifolius seedlings subjected to different concentrations of Azadirachta indica extract.

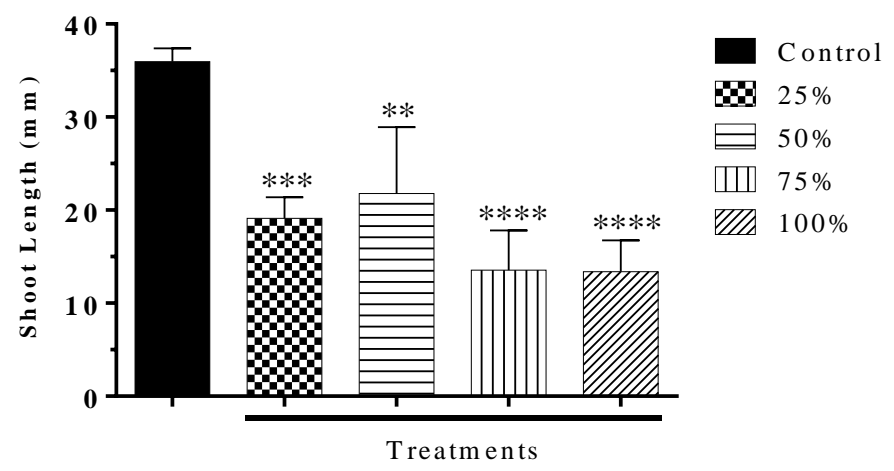

One-way analysis of variance (ANOVA). Mean ( \pm standard deviation). ns: no statistical significance. $* \mathrm{p}<0.05$ compared to the control. Source: Authors (2021). 
Figure 5: Development of the radicle of Handroanthus serratifolius seedlings submitted to different concentrations of Azadirachta indica extract.

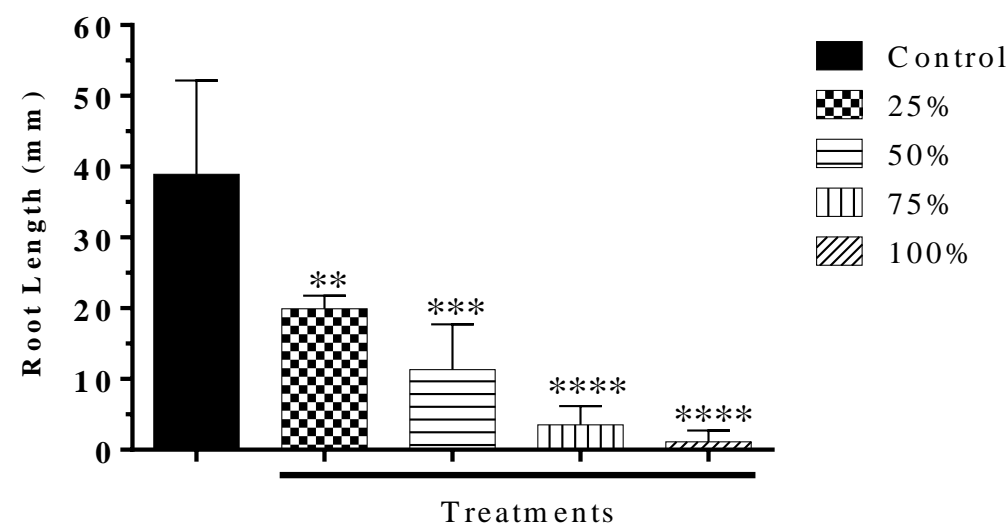

One-way analysis of variance (ANOVA). Mean ( \pm standard deviation). ns: no statistical significance. ${ }^{*} \mathrm{p}<0.05$ compared to the control. Source: Authors (2021).

It was verified that the values of $\mathrm{pH}$ and osmotic potency of the extract of the leaves of Azadirachta indica in the different treatments varied between 6.50 and 7.11 and $-0.05 \mathrm{MPa}$ and $-0.25 \mathrm{MPa}$ respectively (Table 1). The pH values are in accordance with the acceptable standards for germination and seedling development in allelopathy experiments, since, according to Roy et al., (2006) the pH range below 4 and above 10 deleteriously affect the germination and seedling growth. Regarding the osmolarity values, it was observed that the value found in the $100 \%$ concentration is within the acceptable limit. According to Gatti et al., (2004) the osmotic potential cannot exceed -0.2 MPa, since higher values can influence and/or mask the allelopathic action.

Table 1. Physicochemical values of Azadirachta indica extract used in Handroanthus serratifolius germination bioassays.

\begin{tabular}{ccc}
\hline Treatments & pH & Osmolarity (MPa) \\
\hline $25 \%$ & 6,50 & $-0,05224128$ \\
$50 \%$ & 6,53 & $-0,1249248$ \\
$75 \%$ & 6,51 & $-0,1930656$ \\
$100 \%$ & 7,11 & $-0,25439232$ \\
\hline
\end{tabular}

Source: Authors (2021).

The phytochemical analysis of Azadirachta indica extract showed the presence of alkaloids, catechins, phenols and several constituents belonging to the flavonoid group, such as flavonols, flavones, flavonones, chalcones, aurones and leucoanthocyanidins (Table 2). Phytochemical characterization, even if preliminary, can help to understand the effects exerted by plant extracts on different organisms (Costalonga, 2017). Some classes of plant secondary metabolites, such as alkaloids, terpenoids and phenolic compounds, function as a chemical defense of plants (Viegas Jr, 2003). 
Table 2. Classes of secondary metabolites found in Azadirachta indica extract used in Handroanthus serratifolius germination bioassays.

\begin{tabular}{cc}
\hline Chemical constituents & Treatments \\
\hline Alkaloid & + \\
Anthocyanins and Anthocyanidins & - \\
Catechins & + \\
Chalcones and Aurones & + \\
Phenols & + \\
Flavones, Flavonols and Xanthones & + \\
Flavanones & + \\
Flavanonols & - \\
Leukoanthocyanidins & + \\
Condensed tannins & - \\
Hydrolysable tannins & - \\
\hline
\end{tabular}

Source: Authors (2021).

It is likely that the compounds from the secondary metabolism of Azadirachta indica may be related to the allelopathic action, observed in this research since such substances are capable of inducing oxidative enzymes that cause the reduction of growth and development of seedlings.

\section{Final Considerations}

The presence of $A$. indica can cause risks to native species, since it can inhibit the germination of its seeds and/or the development of its seedlings, due to the allelopathic potential presented by that species, being necessary more detailed studies in order to determine the real impact of its introduction in natural environments.

It is recommended to carry out more effective chemical analyzes in order to identify and isolate the allelochemicals responsible for the observed allelopathic activity, since such compounds, once isolated, can be used as natural herbicides controlling weedy species without causing damage to the environment.

\section{Acknowledgments}

The Ceará Foundation for Support to Scientific and Technological Development (FUNCAP) for granting the scholarship to authors and financial support through the Research Productivity Scholarship Program, stimulus to Interiorization and Technological Innovation (BPI).

\section{References}

Almeida, G. D., Zucoloto, M., Zetun, M. C., Coelho, I., \& Sobreir, F. M. (2008). Estresse oxidativo em células vegetais mediante aleloquímicos. Revista Facultad Nacional de Agronomia Medellin, 1 (61), 4237-4247.

Alves, L. F., \& Metzger, J. P. 2006. Forest regeneration in secondary forest áreas at Morro Grande Forest Reserve, Cotia, SP. Biota Neotropica. 6 (2), 1-26. http://dx.doi.org/10.1590/S1676-06032006000200005.

Azevedo Neto, E. N. 2010. Potencial alelopático de leucena e de sabiá na germinação, na emergência e no crescimento inicial do sorgo. 2010. Monografia (Graduação em Engenharia Florestal) Universidade Federal de Campina Grande, Patos. 29 p.

Barrek, S., Paisse, O., Grenier-Loustalot, M. F. 2004. Analysis of neem oil by LC-EM and degradation kinectics of azadirachtin-A in a controlled environment. Characterization of degradation products by HPLC-MS/MS. Analytical and Bioanalytical Chemistry. 378(3), 753-763, https://doi.org/10.1007/s00216-0032377-0. 
Bogorni, P. C., \& Vendramim, J. D. 2005. Efeito subletal de extratos aquosos de Trichilia spp. sobre o desenvolvimento de Spodoptera frugiperda (J.E. Smith) (Lepidoptera: Noctuidae) em milho. Neotropical Entomology. 34(2), 311-317. https://dx.doi.org/10.1590/S1519-566X2005000200020.

Chung, I. M., Ahn, J. K., \& Yun, S. J. 2001. Assessment of allelopathic potential of Barnyard grass (Echnochloa crusgall) on rice (Oriza sativa L.) cultivars. Crop Protection. South Korea, 20(10), 921-928. https://doi.org/10.1016/S0261-2194(01)00046-1.

Costalonga, S. A. P. 2017. Avaliação alelopática, mutagênica e fitoquímica de extratos vegetais de três espécies exóticas invasoras. Tese (Doutorado em Biologia Vegetal). Programa de Pós-Graduação em Biologia Vegetal da Universidade Federal do Espírito Santo. 199 p.

Dadkhah, A., \& Asaadi, A. M. 2010. Allelopathic effects of Eucalyptus camaldulensis on seed germination and growth seedlings of Acroptilon repens, Plantago lanceolata and Portulaca oleracea. Research of Journal Biologic Science. 5(6), 430-434. http://dx.doi.org/10.3923/rjbsci.2010.430.434.

Ferreira, A. G., Aquila, M. E. A. 2000. Alelopatia: Uma área emergente de ecofisilogia. Revista Brasileira de Fisiologia Vegetal. 2, $175-204$.

Ferreira, A. G., \& Borghetti, F. 2004. Germinação: do básico ao aplicado. Porto Alegre: Artmed, p. 323.

Formagio, A. S. N., Masetto, T. E.; Baldivia, D. S., Vieira, M. C., Zarate, N. A. H., \& Pereira, Z. V. 2010. Potencial alelopático de cinco espécies da família Annonaceae. Revista Brasileira de Biociências. 8(4), 349-354.

Gallo, D., Nakano, O., Neto, S. S., Carvalho, R. P. L., Baptista, G. C., Filho, E. B., Parra, J. R. P., Zucchi, R. A., Alves, S. B., Vendramim, J. D., Marchini, L. C., Lopes, J. R. S., \& Omoto, C. 2002. Entomologia agrícola. Piracicaba: FEALQ.

Gatti, A. B., Perez, S. C., \& Lima, M. I. 2004. Atividade alelopática de extratos aquosos de Aristolochia esperanzae O. Kuntze na germinação e no crescimento de Lactuca sativa L. e Raphanus sativus L. Acta Botânica Brasilica. 18(3), 459-472. http://dx.doi.org/10.1590/S0102-33062004000300006.

Gliessman, S.R. \& Müller, C.H. 1978. The allelopathic mechanisms of dominance in bracken Pteridium aquilinum Southern California. Journal of Chemical Ecology, 4 (3), 337-362.

Inoue, M. H., Santana, D. C., Souza Filho, A. P. S., Possamai, A. C. S., Silva, L. E., Pereira, M. J. B., \& Pereira, K. M. 2010. Potencial alelopático de Annona crassiflora: efeitos sobre plantas daninhas. Planta Daninha. 28(3), 489-498. http://dx.doi.org/10.1590/S0100-83582010000300005.

Jefferson, L. V., \& Pennachio, M. 2003. Allelopathic effect of foliage extracts from four Chenopodiaceae species on seed germination. Journal of Arid Environments. 55(2), 275-285. https://doi.org/10.1016/S0140-1963(03)00028-4.

Koul, O., Isman, M. B., \& Ketkar, C. M. 1990. Use of neem, Azadirachta indica. Canadian Journal of Botany. 68, 1-11. https://doi.org/10.1139/b90-001.

Larcher, W. A. 2004. Ecofisiologia vegetal. São Carlos: Rima Artes e Textos.

Maguire, J. D. 1962. Speed of germination aid in selection and evaluation for seedling emergence and vigor. Crop Sciense. 2(2), 176-177. http://dx.doi.org/10.2135/cropsci1962.0011183X000200020033x.

Matos, A. P. 2006. Busca de compostos inseticidas: Estudo de espécies do gênero Trichilia (Meliaceae). Tese (Doutorado em Ciências - Química Orgânica) São Carlos- SP, Universidade Federal de São Carlos-Instituto de Química, 170 p.

Moro, M. F., \& Westerkamp, C. 2011. The alien street trees of Fortaleza (NE Brazil): qualitative observations and the inventory of two districts. Ciência Florestal. 21(4), 789-798. http://dx.doi.org/10.5902/198050984524.

Oliveira, A. K. M., Coelho, M. F. B., Maia, S. S. S., Diógenes, F. E. P., \& Medeiros Filho, S. 2012. Alelopatia de extratos de diferentes órgãos de mulungu na germinação de alface. Horticultura Brasileira. 30(3), 480-483. http://dx.doi.org/10.1590/S0102-05362012000300020.

Oliveira, A. K. M., Ribeiro, J. W. F., Matias, R., Gusmão, D. H., \& Pereira, K. C. L. 2011. Potencial alelopático de folhas frescas de bacupari (Rheedia brasiliensis (Mart.) Planch. \&Triana) na germinação de alface. Revista Brasileira de Biociências. 9, 550-553.

Oliveira Junior, R. S., \& Constantin, J. 2001. Plantas daninhas e seu manejo. Agropecuária. 1, p. 362.

Rice, E. L. (2012). Allelopathy (2nd ed). Academic press. 368p.

Richardson, D. R., \& Williamson, G. B. 1988. Allelopathic effects of shrubs of the sand pine scrub on pines and grasses of the sandhills. Forest Science. 34(3), 592-605. https://doi.org/10.1093/forestscience/34.3.592.

Rickli, H. C., Fortes, A. M. T, Silva., P. S. S., Pilatti, D. M., \& Hutt, D. R. 2011. Efeito alelopático de extrato aquoso de folhas de Azadirachta indica A. Juss. em alface, soja, milho, feijão e picão-preto. Semina: Ciências Agrárias. Londrina. 32(2), 473-484. http://dx.doi.org/10.5433/1679-0359.2011v32n2p473.

Roy, A., \& Saraf, S. 2006. Limonoids: overview of significant bioactive triterpenes distributed in plants kingdom. Biological \& Pharmaceutical Bulletin. 29(2), 191-201. https://doi.org/10.1248/bpb.29.191

Schmutterer, H. 1990. Properties and potential of natural pesticides from the neem tree, Azadirachta indica. Annual Review of Entomology. 35, 271-297. https://doi.org/10.1146/annurev.en.35.010190.001415.

Souza Filho, A. P. S., Cunha, R. L., \& Vasconcelos, M. A. M. 2009. Efeito inibitório do óleo de Azadirachta indica A. Juss. sobre plantas daninhas. Revista de Ciências Agrárias. 52, 79-86.

Taiz, L., \& Zeiger, E. 2017. Fisiologia Vegetal. (5 ed.) Porto Alegre: Artmed, 820 p.

Turk, M. A., \& Tawaha, A. M. 2002. Inhibitory effects of aqueous extracts of black mustard on germination and growth of lentil. Pakistan Journal of Agronomy. 1, 28-30. http://dx.doi.org/10.3923/ja.2002.28.30.

Viegas Jr, C. 2003. Terpenos om atividade inseticida: uma alternativa para o controle químico de insetos. Quimica Nova. 26(3), 390-400. http://dx.doi.org/10.1590/S0100-40422003000300017. 